\title{
PENGEMBANGAN MODUL PEMBELAJARAN BERBASIS SAINTIFIK DENGAN METODE BERMAIN PERAN PADA MATA PELAJARAN BASA SUNDA KELAS III SD/MI
}

\author{
Pitri Rahayu ${ }^{1}$, Salati Asmahasanah ${ }^{2}$, Syarifah Gustiawati ${ }^{3}$ \\ Pendidikan Guru Madrasah Ibtidaiyah, Universitas Ibn Khaldun Bogor \\ 1'rahayuf539@gmail.com, ${ }^{2}$ Salatiasmahasanah@gmail.com, ${ }^{3}$ liefah83@gmail.com
}

Abstrak: Dilaksanakanya penelitian ini bertujuan untuk mengetahui kelayakan modul pembelajaran dan mengetahui bagaimana proses pengembangan modul pembelajaran berbasis saintifik dengan metode bermain peran pada mata pelajaran Basa Sunda III SD/MI. Penelitian ini menggunakan metode Research and Development (R\&D) dengan menggunakan model penelitian pengembangan Sugiyono. Instrumen penilaian untuk mendapatkan data berupa lembar penilaian validasi modul pembelajaran yang dilaksanakan oleh tiga pakar/ahli yaitu: ahli materi, ahli Bahasa dan ahli desain. Diperoleh persentase kelayakan pada modul pembelajaran dengan persentase ahli materi sebesar 90,3\% dengan kategori "sangat baik" tidak revisi, hasil penilaian ahli Bahasa $71,1 \%$ dengan kategori "baik" tidak revisi, hasil penilaian ahli desain 84,3\% dengan kategori "sangat baik" tidak revisi. Dapat disimpulkan berdasarkan penilain validasi pakar/ahli (materi, Bahasa dan desain) pengembangan modul pembelajaran berbasis saintifik dengan metode bermain pada mata pelajaran Basa Sunda kelas III SD/MI dinyatakan valid atau baik diterapkan untuk memudahkan guru dalam menyampaikan materi pada siswa.

\section{Kata Kunci: Modul, saintifik, pembelajaran Basa Sunda}

\section{DEVELOPMENT OF SCIENTIFIC BASED LEARNING MODULES WITH ROLE-PLAYING METHODS IN SUNDANESES CLASS III SD/MI}

\begin{abstract}
The implementation of this research aims to determine the feasibility of the learning module and to find out how the process of developing a scientific-based learning module with the role-playing method in Sundanese III SD / MI subjects. This study used the Research and Development (R\&D) method using the Sugiyono development research model. The assessment instrument for obtaining data was in the form of a learning module validation assessment sheet carried out by three experts, namely: material experts, linguists and design experts. The percentage of eligibility in the learning module was obtained with a percentage of material experts of $90.3 \%$ with the category "very good" not revised, the results of the assessment of language experts $71.1 \%$ with the category of "good" not revised, the results of the design expert's assessment of $84.3 \%$ with the category "Excellent" no revision. It can be concluded that based on expert/expert validation assessment (material, language, and design), the development of a scientific-based learning module with the playing methods in Sundanese class III SD / MI is declared valid or well applied to assist teacher in providing material to students.
\end{abstract}

Key Words: Module, scientific, Sundanese learning 


\section{PENDAHULUAN}

Bahasa Sunda merupakan salah satu Muatan Lokal (mulok) yang wajib disetiap jenjang pendidikan, mata pelajaran Basa Sunda diajarkan mulai dari SD/MI, SMP/MTS, SMA/MA. Menurut kurikulum pendidikan dasar mata pelajaran yang terdapat disekolah salah satunya meliputi muatan lokal dimana Bahasa daerah merupakan salah satu muatan lokal yang wajib. Muatan lokal berfungsi untuk mengembangkan kemampuan siswa yang perlu diperhatiakn oleh daerah yang bersangkutan sesuai dengan keadaan lingkungan dan ciri khas satuan pendidikan yang bersangkutan dengan mengacu kepada kurikulum yang berlaku secara Nasional (Pasal 14 ayat 3 PP No 28 Tahun 1990).

Kurikulum 2013 mengacu pada proses pembelajaran dengan pendekatan saintifik. Pendekatan saintifik memiliki keistimewaan dimana proses pembelajaran berpusat pada siswa. Penerapan dengan menggunakan pendekatan saintifik dalam proses belajar disekolah bertujuan untuk melatih peserta didik dalam berfikir, berkarya dan bersikap sesuai dengan pedoman dan langkah ilmiah (Nurdyansya \& Musfiqon, 2015:57). Prisip-prinsip pendekatan saintifik yaitu : (a) melibatkan siswa berperan aktif dalam proses pembelajaran dan guru sebagai fasilitator, (b) dari proses pengalaman belajar langsung siswa dapat menuangkan ide-ide yang dimilikinya (students self concept), (c) belajar menggunakan pendekatan saintifik mengandung tahap: mengamati, menanya, menalar, mencoba dan mengkomunikasikan kembali ide atau gagasan tersebut kepada teman-temannya, (d) mendorong dan meningkatkan kemampuan berfikir siswa, siswa belajar mengkonstruk pengetahuan yang dimiliki dengan mengaitkan beberapa cabang ilmu, (e) meningkatkan motivasi belajar siswa dan (f) memberikan kesempatan kepada siswa dalam meningkatkan kemampuan berkomunikasi (Mulyasari dkk, 2019).

Materi pembelajaran Bahasa Sunda yang dilakukan oleh guru cenderung mengunakan pendekatan konvensional dan mengunakan metode atau media yang monoton dan membosankan, sehingga menyebabkan siswa tidak aktif dalam belajar dan menganggap bahwa mata pelajaran Basa Sunda itu sulit dan membosankan. Salah satu upaya untuk mendorong minat siswa pada penelitian ini berupa modul pembelajaran yang dikemas secara menarik dan menantang kreatifitas siswa. Modul merupakan bahan ajar cetak yang disusun secara sitematis agar mudah dipelajari siswa secara mandiri (Susilo, 2015). Modul pembelajaran secara umum pada dasarnya merupakan semua bahan ajar untuk belajar (Budi, 2019). Modul merupakan bahan ajar yang dirancang berdasarkan kurikulum dan dikemas dalam bentuk satu pelajaran dengan sistematis yang dapat digunakan secara mandiri oleh siswa (Setiyadi M. W., 2017). Dapat kesimpulan bahwa modul pembelajaran merupakan produk terprogram dibuat oleh guru secara sistematis untuk mempermudah dan menjadi daya tarik siswa memahami materi pembelajaran secara mandiri.

Dari hasil wawancara dengan guru kelas III MI Tarbiyatusshibyan Bogor menunjukan bahwa proses pembelajaran Basa Sunda masih menggunakan metode yang sederhana dan proses pembelajaran yang pasif, membuat siswa sulit menangkap materi yang diajarkan. Salah satu upaya yan dilakuakan oleh guru dalam proses belajar adalah menggunakan modul pembelajaran.

\section{METODE}

Metode penelitian ini menggunakan metode Research and Development (R\&D). Menurut Sugiyono (2015 : 409) Research and Development (R\&D) adalah sebuah metode penelitian yang digunakan untuk menghasilkan produk tertentu dan menguji keberhasilan produk tersebut. Perencanaan pengembangan modul pembelajaran ini 
berpedoman pada pendekatan dari Sugiono yaitu terdiri dari 10 tahapan (Sugiyono, 2015 : 409) yang dilihat dalam gambar berikut:

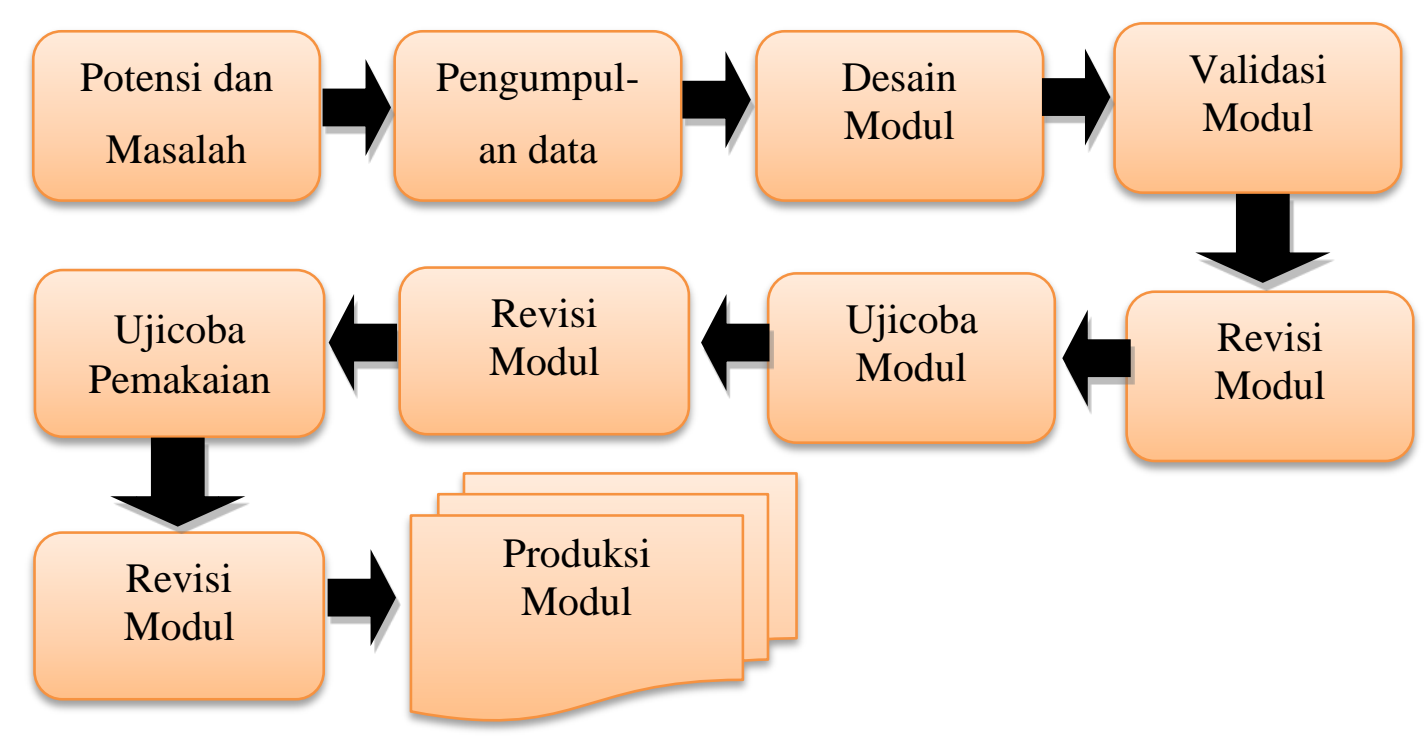

Gambar 3.1 Langkah-langkah Penggunaan Metode R\&D Sugiyono

Adapun taghapan pelaksanaan yang dilakukakan dalam penelitian pengembangan modul berbasis saintifik dengan metode bermain peran pada mata pelajaran Basa Sunda hanya pada tahap validasi.

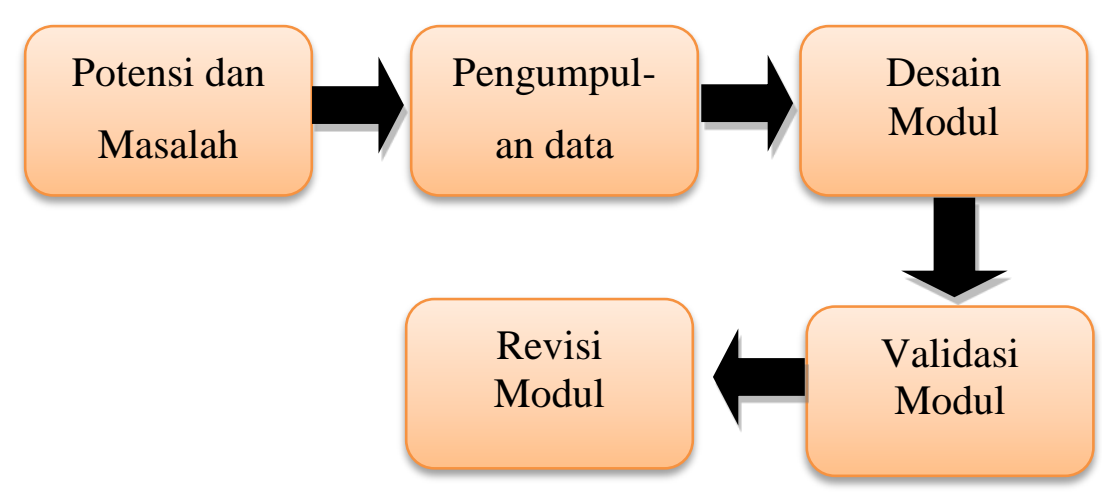

Gambar 3.2 Langkah-langkah Penggunaan Metode R\&D Sugiyono

Langkah-langkah penelitian ini dilakukan hanya sampai pada tahap validasi desain, kemudian peneliti melakukan perbaikan pada modul berdasarkan komentar, kritik dan saran dari para ahli, dikarenakan adanya pandemi COVID-19 yang melanda dihampir seluruh Negara termasuk di Indonesia dan mengakibatkan keterhambatan peneliti dalam proses menyempurnakan langkah-langkah Research and Development (R\&D) yang sesuai dengan teori Sugiyono. Ditengah wabah pandemi Covid-19 pemerintah menerapkan kebijakan physical distancing dibanyak wilayah yang mengakibatkan hambatan-hambatan dalam proses penelitian, seperti sulitnya mendapatkan literatur pendukung di lapangan dan akses ke narasumber yang terbatas. Terdapat beberapa peraturan yang dikeluarkan oleh pemerintah yang memaksa siswa 
belajar mandiri dirumah yang mengakibatkan pada ujicoba kesekolah tidak dapat memungkinkan untuk dilakukan. Sehingga peneliti hanya dapat menyelesaikan pengembangan modul ini pada tahap validasi para ahli agar penelitian ini tetap berjalan dan tidak menghambat kelulusan. Prosedur penelitian yang dilakukan dalam penelitian ini menggunakan metode penelitian Reseach and Development (R\&D). Berikut masingmasing penjelasannya:

1. Tahap potensi dan masalah

Hasil dari pengumpulan informasi yang didapat bahwa perlunya bahan ajar berupa modul pembelajaran dengan metode yang tepat guna menumbuhkan keaktifan siswa dalam proses pembelajaran. Cara yang digunakan dalam memperoleh informasi tersebut peneliti melakukan wawancara ke nasasumber yaitu guru kelas III MI Tarbiyatusshibyan Bogor dan observasi langsung ke sekolah. Hasil dari wawancara berupa acuan penguatan pembuatan modul pembelajaran Basa Sunda berbasis saintifik dengan metode bermain peran untuk meningkatkan keterampilan berbicara siswa. Data yang dikumpulkan berupa Kompetensi Dasar yang dibutuhkan siswa, nilai hasil ujian semester ganjil, buku acuan dan jurnal yang berkaitan tentang pengembangan modul pembelajaran.

2. Pengumpulan Data

Data yang dikumpulkan berupa Kompetensi Dasar yang dibutuhkan siswa, nilai hasil ujian semester ganjil, buku acuan dan jurnal yang berkaitan tentang pengembangan modul pembelajaran.

3. Tahap Desain Modul

Pada tahap ini peneliti melakukan desain produk berdasarkan data yang telah diperoleh dari sekolah yang bertumpu pada kebutuhan siswa dalam pembelajaran Basa Sunda berupa produk. Peneliti membuat desain produk dengan warna, bentuk dan gambar yang menarik, kemudian modul pembelajaran dikembangkan guna meningkatkan keterampilan berbicara siswa.

4. Tahap Validasi Modul

Untuk mengetahui kelayakan pengembangan modul pembelajaran yang dilakukan oleh tiga pakar/ahli, yaitu ahli materi, ahli Bahasa, dan ahli desain yang masing-masing ahli dalam bidangnya. Peneliti menerima masukan, kritik dan saran dari para ahli guna memperoleh hasil modul pembelajaran yang berkualitas.

5. Tahap Revisi Modul

Tindakan selanjutnya adalah revisi modul pembelajaran untuk memperbaiki dan dan menambahkan pada modul pembelaajran sesuai komentar, krtitik dan saran dari para ahli. Kemudian dilakukan perbaikan oleh peneliti berdasarkan masukan, keritik dan saran yang diberikan oleh pakar/ahli guna menghasilkan modul pembelajaran yang berkualitas.

Jenis data yang diperoleh dari penelitian ini merupakan data kualitatif. Data yang diperoleh dari hasil penilaian validasi merupakan bentuk angka yang nantinya akan dideskripsikan untuk mengetahui hasil kelayakan pengembangan modul pembelajaran menurut para ahli (ahli materi, ahli Bahasa, ahli desain).

\section{HASIL DAN PEMBAHASAN Hasil}

Pengembangan modul pembelajaran dibatasi hanya sampai pada tahap validasi para ahli dikarenakan adanya pandemi Covid-19 yang mengakibatkan pada tahap uji coba kesekolah tidak memungkinkan untuk dilakukan. Berikut penjelasan tiap tahapan 
dalam penelitian dan pengembangan modul:

1. Tahap Potensi dan Masalah

Untuk mengetahui potensi dan masalah peneliti menganalisis kebutuhan siswa kelas III di MI Tarbiyatusshibyan dan menganalisis kurikulum di sekolah.

2. Mengumpulkan Informasi

Peneliti mengumpulkan informasi yang berkaitan dengan metode pembelajaran, materi dan desain melalui wawancara, kajian berbagai buku, jurnal dan artikel yang mudah didapat melalui internet untuk mempermudah pembuatan modul pembelajaran.

3. Desain Modul

Produk yang dihasilkan dalam penelitian ini adalah modul pembelajaran Basa Sunda kelas III SD/MI berbasis saintifik dengan metode bermain peran.

4. Validasi Modul

Berdasarkan penelitian yang telah dilakukan dalam pengembangan modul pembelajaran dan telah dilaksanakannya validasi terhadap modul pembelajaran berdasarkan para ahli. Kriteria kelayakan modul pembelajaran ini berupa kevalidan untuk merevisi modul pembelajaran, kriteria tersebut digunakan sebagai pedoman peneliti untuk melihat kevalidan modul apakah layak digunakan atau harus direvisi. Berikut kriteria kelayakan modul pembelajaran.

Table 4.3 Kriteria interval Persentase

\begin{tabular}{|l|c|c|c|c|}
\hline No & Interval Persentase & Kriteria & Keteranngan & Kualifikasi \\
\hline 1. & $80 \%-100 \%$ & Sangat Baik & Tidak Revisi/Baik & Sangat Valid \\
\hline 2. & $66 \%-79 \%$ & Baik & Tidak Revisi/Baik & Valid \\
\hline 3. & $56 \%-79 \%$ & Cukup & Revisi/Tidak Baik & Cukup Valid \\
\hline 4. & $40 \%-55 \%$ & Kurang Baik & Revisi/Tidak Baik & Kurang Valid \\
\hline 5. & $0 \%-39 \%$ & Tidak Baik & Revisi/Tidak Baik & $\begin{array}{c}\text { Sangat } \\
\text { Kurang Valid }\end{array}$ \\
\hline
\end{tabular}

Berdasarkan tabel diatas mengenai tingkat kelayakan modul pembelajaran. Persentase kelayakan modul pembelajaran dinyatakan layak atau baik dengan kriteria 61-100\% dari seluruh unsur angket yang dinyatakan dalam memvalidasi ahli materi, ahli Bahasa dan ahli desain. Penilaian ini bertujuan untuk mengetahui kelayakan modul pembelajaran yang telah dibuat. Berikut hasil penilaian validasi modul pembelajaran modul pembelajaran ahli materi.

a. Hasil Validasi Ahli Materi

Validasi ahli materi dilaksanakan oleh bapak Misbahudin Januari selaku guru mata pelajaran Basa Sunda sekaligus merangkap sebagai wali kelas III di MI Tarbiyatusshibyan yang mempunyai latar belakang sesuai dengan materi yang dikembangkan.

1) Aspek Kelayakan Isi

\begin{tabular}{|c|c|c|}
\hline & Butir pertanyaan & Skor \\
\hline \multirow{4}{*}{$\begin{array}{c}\text { Kesesuain } \\
\text { antara SK KD }\end{array}$} & 1. Kelengkapan materi & 4 \\
\hline & 2. $\quad$ Keluasan materi & 3 \\
\hline & 3. Kedalaman materi & 3 \\
\hline & $\begin{array}{l}\text { 4. Isi modul sesuai dengan } \\
\text { perkembangan jaman }\end{array}$ & 3 \\
\hline Ketepatan & 5. Ketepatan konsep dan & 3 \\
\hline
\end{tabular}




\begin{tabular}{|c|c|c|}
\hline \multirow[t]{5}{*}{ materi } & definisi & \\
\hline & $\begin{array}{l}\text { 6. Ketepatan data dan } \\
\text { fakta }\end{array}$ & 4 \\
\hline & $\begin{array}{l}\text { 7. Ketepatan gambar dan } \\
\text { ilustrasi }\end{array}$ & 4 \\
\hline & 8. $\quad$ Ketepatan istilah & 4 \\
\hline & $\begin{array}{l}\text { 9. Ketepatan acuan } \\
\text { Pustaka }\end{array}$ & 4 \\
\hline \multirow[t]{4}{*}{$\begin{array}{c}\text { Kemutakhiran } \\
\text { materi }\end{array}$} & $\begin{array}{l}\text { 10. Materi dapat } \\
\text { mengembangkan rasa } \\
\text { ingin tahu }\end{array}$ & 4 \\
\hline & $\begin{array}{l}\text { 11. Menggunakan gambar } \\
\text { dan contoh sesuai } \\
\text { lingkungan }\end{array}$ & 4 \\
\hline & $\begin{array}{l}\text { 12. Menggunakan contoh } \\
\text { dan kasus dalam } \\
\text { kehidupan sehari- hari }\end{array}$ & 3 \\
\hline & 13. Kemutlakan Pustaka & 3 \\
\hline \multirow[t]{2}{*}{$\begin{array}{l}\text { Meningkatkan } \\
\text { rasa ingintahu }\end{array}$} & $\begin{array}{l}\text { 14. Meningkatakan rasa ingin } \\
\text { tahu siswa }\end{array}$ & 4 \\
\hline & $\begin{array}{l}\text { 15. Menciptakan } \\
\text { kemampuan bertanya }\end{array}$ & 4 \\
\hline
\end{tabular}

2) Aspek Kelayakan Penyajian Sumber: Hasil angket

\begin{tabular}{|c|c|c|}
\hline $\begin{array}{l}\text { Kriteria } \\
\text { Penilaian }\end{array}$ & Butir Pertanyaan & Skor \\
\hline \multirow[t]{2}{*}{$\begin{array}{c}\text { Teknik } \\
\text { penyajian }\end{array}$} & $\begin{array}{l}\text { 1. Konsistensi sistematika } \\
\text { sajian dalam kegiatan } \\
\text { belajar }\end{array}$ & 3 \\
\hline & 2. Keruntunan konsep & 3 \\
\hline \multirow{7}{*}{$\begin{array}{l}\text { Pendukung } \\
\text { penyajian }\end{array}$} & $\begin{array}{l}\text { 3. Contoh soal dalam } \\
\text { setiap kegiatan } \\
\text { pembelajaran }\end{array}$ & 4 \\
\hline & 4. Daftar isi & 4 \\
\hline & $\begin{array}{lll}\text { 5. } & \text { Soal evaluasi } & \text { pada } \\
& \text { setiap } & \\
\text { pembelajaran } & \text { akhir }\end{array}$ & 4 \\
\hline & $\begin{array}{l}\text { 6. Kunci jawaban soal } \\
\text { latihan }\end{array}$ & 3 \\
\hline & 7. Glosarium & 3 \\
\hline & 8. Rangkuman & 4 \\
\hline & 9. Daftar pustaka & 4 \\
\hline $\begin{array}{l}\text { Penyampaian } \\
\text { pembelajaran }\end{array}$ & 10. Melibatkan siwa & 4 \\
\hline $\begin{array}{l}\text { Kohetansi dan } \\
\text { keruntutan alur } \\
\text { pikir }\end{array}$ & $\begin{array}{l}\text { 11. Keutuhan makna dalam } \\
\text { kegiatan pembelajaran }\end{array}$ & 4 \\
\hline
\end{tabular}




\begin{tabular}{|l|c|}
\hline Jumlah Keseluruhan & 94 \\
\hline Rata-rata & 3,6 \\
\hline
\end{tabular}

Sumber: Hasil angket

Berdasarkan hasil penilaian pada tabel 4.3 menunjukan skor yang diperoleh sebesar 94 dari skor total 104 maka dapat dihitung persentase hasil validasi ahli materi sebagai berikut:

$$
\begin{aligned}
& P=\frac{F}{N} \times 100 \\
& P=\frac{94}{104} \times 100=90,3 \%
\end{aligned}
$$

Berdasarkan hasil penghitungan diatas jika dikonversikan dalam bentuk persentase maka diperoleh hasil 90,3\%. Hasil validasi ini menunjukan hasil yang sangat baik atau kriteria yang sangat valid.

b. Hasil Validasi Ahli Bahasa

Validasi ahli Bahasa dilaksanakan oleh bapak Irfan Supriatna, S.Pd., M.Pd selaku dosen di Universitas Bengkulu. Validasi ahli Bahasa bertujuan untuk mendapat komentar, kritik dan saran agar modul pembelajaran yang dikembangkan

\begin{tabular}{|c|c|c|}
\hline Kriteria Penilian & Butir Penilaian & Skor \\
\hline \multirow[t]{3}{*}{ Lugas } & $\begin{array}{l}\text { 1. Ketepatan struktur } \\
\text { kalimat }\end{array}$ & 2 \\
\hline & $\begin{array}{ll}\text { 2. } & \text { Menggunakan } \\
& \text { kalimat yang efektif }\end{array}$ & 3 \\
\hline & 3. Kebakuan istilah & 2 \\
\hline Mudah difahami & $\begin{array}{l}\text { 4. Pemahaman terhadap } \\
\text { pesan atau informasi }\end{array}$ & 3 \\
\hline \multirow[t]{2}{*}{ Dialogis dan interaktif } & $\begin{array}{ll}\text { 5. } & \text { Kemampuan } \\
\text { memberikan motivasi } \\
\text { kepada siswa }\end{array}$ & 3 \\
\hline & $\begin{array}{l}\text { 6. Melatih untuk berfikir } \\
\text { kritis }\end{array}$ & 3 \\
\hline \multirow[t]{2}{*}{$\begin{array}{c}\text { Sesuai dengan } \\
\text { kebutuhan siswa }\end{array}$} & $\begin{array}{ll}\text { 7. } & \text { Sesuai dengan } \\
\text { kebutuhan materi } \\
\text { siswa }\end{array}$ & 3 \\
\hline & $\begin{array}{l}\text { 8. } \\
\text { Sesuaian dengan } \\
\text { perkembangan } \\
\text { emosional siswa }\end{array}$ & 3 \\
\hline \multirow{3}{*}{$\begin{array}{c}\text { Sesuaian dengan } \\
\text { tuntunan Basa Sunda }\end{array}$} & 9. $\quad$ Ketepatan ejaan & 3 \\
\hline & 10. Ketepatan tata bahasa & 4 \\
\hline & $\begin{array}{l}\text { 11. } \begin{array}{l}\text { Keterkaitan dan } \\
\text { keutuhan makna }\end{array}\end{array}$ & 3 \\
\hline
\end{tabular}
menjadi produk yang berkualitas secara aspek kelayakan Bahasa. 


\begin{tabular}{|c|c|c|}
\hline \multirow[t]{2}{*}{$\begin{array}{l}\text { Penggunaan istilah dan } \\
\text { simbol }\end{array}$} & $\begin{array}{ll}\text { 12. } & \text { Konsisten dalam } \\
\text { menggunakan istilah }\end{array}$ & 2 \\
\hline & $\begin{array}{l}\text { 13. Konsisten dalam } \\
\text { menggunakan tanda } \\
\text { baca }\end{array}$ & 3 \\
\hline & $\begin{array}{l}\text { Jumlah } \\
\text { Keseluruhan }\end{array}$ & 37 \\
\hline & Rata-rata & 2,8 \\
\hline
\end{tabular}

Sumber: Hasil angket

Berdasarkan hasil penilaian pada tabel 4.3 menunjukan skor yang diperoleh sebesar 37 dari skor total 52 maka dapat dihitung persentase hasil validasi ahli Bahasa sebagai berikut:

$$
\begin{aligned}
& P=\frac{F}{N} \times 100 \\
& P=\frac{37}{52} \times 100=71,1 \%
\end{aligned}
$$

Berdasarkan hasil penghitungan diatas jika dikonversikan dalam bentuk persentase maka diperoleh hasil $71,1 \%$. Hasil validasi ini menunjukan hasil yang baik atau kriteria yang valid.

c. Hasil Validasi Ahli Desain

Validasi ahli desain dilakukan oleh ibu Maimunah, M.Pd selaku dosen Teknologi Pendidikan, Fakultas Keguruan dan Ilmu Pendidikan, Universitas Ibn Khaldun Bogor. Validasi ahli desain bertujuan untuk mendapat komentar, kritik dan saran supaya modul pembelajaran yang dikembangkan menjadi produk yang

\begin{tabular}{|c|c|c|}
\hline $\begin{array}{l}\text { Kriteria } \\
\text { Penilian }\end{array}$ & Butir Penilaian & Skor \\
\hline \multirow[t]{2}{*}{$\begin{array}{l}\text { Ukuran } \\
\text { Modul }\end{array}$} & $\begin{array}{l}\text { 1. Ukuran modul sesuai dengan } \\
\text { standar ISO (A4, B5, dan B5) }\end{array}$ & 4 \\
\hline & $\begin{array}{l}\text { 2. Kesesuaian ukuran dengan materi } \\
\text { isi modul }\end{array}$ & 3 \\
\hline \multirow[t]{3}{*}{$\begin{array}{l}\text { Tata letak } \\
\text { kulit } \\
\text { modul }\end{array}$} & $\begin{array}{l}\text { 3. Tampilan unsur tata letak pada } \\
\text { sampul muka, belakang dan } \\
\text { punggung memiliki kesatuan } \\
\text { serta konsisten. }\end{array}$ & 3 \\
\hline & $\begin{array}{l}\text { 4. Komposisi unsur tata letak (judul } \\
\text { pengarang, ilustrasi, logo, dll) } \\
\text { sesua dengan tata letak isi }\end{array}$ & 3 \\
\hline & $\begin{array}{ll}\text { 5. } & \begin{array}{l}\text { Ukuran unsur tata letak } \\
\text { proporsional }\end{array}\end{array}$ & 3 \\
\hline \multirow{2}{*}{$\begin{array}{l}\text { Tata letak } \\
\text { kulit } \\
\text { modul }\end{array}$} & 6. Memiliki kekontrasan yang baik & 3 \\
\hline & 7. $\begin{array}{l}\text { Penampilan unsur tata letak } \\
\text { konsisten }\end{array}$ & 3 \\
\hline $\begin{array}{l}\text { Tripografi } \\
\text { kulit } \\
\text { modul }\end{array}$ & $\begin{array}{l}\text { 8. Ukuran huruf judul buku lebih } \\
\text { dominan dibandingkan nama } \\
\text { pengarang }\end{array}$ & 3 \\
\hline
\end{tabular}
berkualitas secara aspek kelayakan desain. 


\begin{tabular}{|c|c|c|}
\hline & $\begin{array}{l}\text { 9. Warna judul buku lebih kontras } \\
\text { dengan warna latar belakang }\end{array}$ & 3 \\
\hline & $\begin{array}{l}\text { 10. Huruf yang digunakan menarik } \\
\text { dan mudah dibaca }\end{array}$ & 4 \\
\hline & $\begin{array}{l}\text { 11. Tidak terlalu banyak } \\
\text { menggunakan kombinasi huruf }\end{array}$ & 4 \\
\hline \multirow{2}{*}{$\begin{array}{l}\text { Ilustrasi } \\
\text { kulit } \\
\text { modul }\end{array}$} & 12. Menggambarkan isi/materi ajar & 4 \\
\hline & $\begin{array}{l}\text { 13. Bentuk, warna, ukuran, properti } \\
\text { obyek sesuai realita }\end{array}$ & 3 \\
\hline \multirow[t]{6}{*}{$\begin{array}{l}\text { Tata letak } \\
\text { isi modul }\end{array}$} & $\begin{array}{l}\text { 14. Penampilan unsur tata letak } \\
\text { konsisten berdasarkan pola }\end{array}$ & 3 \\
\hline & $\begin{array}{l}\text { 15. Penempatan judul dan bab setara } \\
\text { (kata pengantar, daftar isi, dan } \\
\text { lainnya seragam serta konsisten) }\end{array}$ & 4 \\
\hline & $\begin{array}{l}\text { 16. } \begin{array}{l}\text { Bidang cetak dan margin } \\
\text { proporsional }\end{array} \\
\text { pror }\end{array}$ & 3 \\
\hline & $\begin{array}{l}\text { 17. Spasi antara teks dan ilustrasi } \\
\text { sesuai }\end{array}$ & 3 \\
\hline & $\begin{array}{l}\text { 18. Margin antara dua halaman } \\
\text { berdampingan proposional }\end{array}$ & 3 \\
\hline & $\begin{array}{l}\text { 19. Penempatan judul, subjudul, } \\
\text { ilustrasi dan keterangan gambar } \\
\text { tidak mengganggu pembahasan }\end{array}$ & 4 \\
\hline \multirow[t]{2}{*}{$\begin{array}{l}\text { Tripografi } \\
\text { isi modul }\end{array}$} & $\begin{array}{l}\text { 20. Tidak menggunakan banyak jenis } \\
\text { huruf }\end{array}$ & 4 \\
\hline & $\begin{array}{l}\text { 21. Penggunaan variasi huruf (bold, } \\
\text { italic, capital) tidak berlebihan }\end{array}$ & 4 \\
\hline \multirow{3}{*}{$\begin{array}{l}\text { Ilustrasi } \\
\text { isi modul }\end{array}$} & 22. Ilustrasi isi modul & 4 \\
\hline & 23. Bentuk proposional & 3 \\
\hline & $\begin{array}{l}\text { 24. Penyajian keseluruhan ilustrasi } \\
\text { menarik dan serasi }\end{array}$ & 3 \\
\hline \multicolumn{2}{|r|}{ Jumlah Keseluruhan } & 81 \\
\hline \multicolumn{2}{|r|}{ Rata-rata } & 3,3 \\
\hline
\end{tabular}

Sumber: Hasil angket

Berdasarkan hasil penilaian pada table 4.4 tersebut, skor yang diperoleh sebesar 81 dari skor total 96jh maka dapat dihitung persentase hasil validasi ahli desain sebagai berikut :

$$
\begin{aligned}
& P=\frac{F}{N} \times 100 \\
& P=\frac{81}{96} \times 100=\mathbf{8 4 , 3}
\end{aligned}
$$

Berdasarkan hasil penghitungan diatas jika dikoversikan dalam bentuk persentase maka diperoleh $84,3 \%$. Hasil validasi ini menunjukan hasil yang sangat baik atau kriteria sangat valid. 


\section{Revisi Modul}

Setelah melaksanakan tiga tahap validasi yaitu ahli materi, ahli Bahasa dan ahli desain. Peneliti menerima komentar, kritik dan saran untuk melakukan perbaikan modul pembelajaran yang sifatnya membangun, demi menghasilkan modul pembelajaran yang berkualitas.

Pembahasan
Berdasarkan validasi yang telah dilaksanakan oleh tiga validator/ahli mendapatkan hasil penilaian dari ahli materi diperoleh hasil 90,3\%, hasil validasi ini menunjukan hasil yang sangat baik atau kriteria yang sangat valid. Berdasarkan hasil penialaian ahli Bahasa diperoleh hasil $71,1 \%$, hasil validasi ini menunjukan hasil yang baik atau kriteria yang valid. Berdasarkan hasil penialaian ahli desain diperoleh $84,3 \%$, hasil validasi ini menunjukan hasil yang sangat baik atau kriteria sangat valid. Dari hasil ketiga validator tersebut menunjukan modul pembelajaran yang dikembangkan baik dan layak untuk diterapkan untuk membantu guru dalam memberikan materi pada siswa.

Hasil penelitian ini didukung dengan beberapa hasil penelitian sebelumnya yang menggunakan penelitain Research and Development (R\&D) dengan fokus penelitian berupa validasi (Exsperts Judgement) untuk mengetahui validitas modul pembelajaran dengan menggunakan angket untuk memperoleh penilaian kelayakan modul disamping itu, hasil penelitian Irma Damayanti menjukkan bahwa penelitiannya menghasilkan satu produk berorientasi pendekatan saintifik dengan spesifikasi pada desain, materi dan penugasan yang berorientasi pendekatan saintifik (Damayanti. Irma, 2017), Setiyadi juga menunjukkan hasil penelitiannya bahwa modul pembelajaran biologi berbasis pendekatan saintifik bersifat valid, praktis, dan efektif. Dikatakan valid karena Modul pembelajaran biologi berbasis pendekatan saintifik yang dikembangkan telah memenuhi kriteria kevalidan dengan kategori "Valid" (Setiyadi, 2017).

Komentar, kritik dan saran dari pakar/ahli materi yang diberikan adalah tambahkan nilai-niali pendidikan Islam kedalam materi pembelajaran. Komentar, kritik dan saran dari pakar/ahli Bahasa terhadap pengembangan modul pembelajaran adalah harus hati-hati dalam pemiliha kata yang tepat untuk pemilihan kata-kata dalam Bahasa Sunda, karena Basa Sunda memiliki banyak persamaan makna (sinonim) dalam satu kata. Komentar, kritik dan saran dari pakar/ahli desain terhadap pengembangan modul pembelajaran adalah gunakan gambar, warna dan bentuk yang menarik untuk menarik perhatian siswa dalam menggunakan modul pembelajaran dan belajar mandiri yang menyenangkan.

Berdasarkan hasil observasi yang dilakukan di MI Tarbiyatusshibyan secara umum siswa melakukan kegiatan belajar dengan baik. Pembelajaran yang gunakan oleh guru masih menggunakan metode konvensional yang mengakibatkan siswa tidak aktif dalam proses belajar. Metode bermaian peran belum pernah diterapkan di kelas III MI Tarbiyatusshibyan khususnya pada mata pelajaran Basa Sunda. Bermain peran akan meningkatkan minat siswa terhadap materi yang diajarkan dan memacu siswa untuk memandang suatu permasalahan dari sudut yang berbeda (Salati, 2018).

Kurangnya bahan ajar yang dapat mendukung siswa belajar aktif. Dari beberapa masalah yang ditemukan, bahwasannya harus ada trobosan baru guna meningkatkan siswa belajar aktif yaitu modul pembelajaran berupa bahan ajar yang dikemas secara utuh dan sistematis, yang didalamnya memuat beberapa pengalaman belajar yang terencana dan didesain untuk membantu siswa dalam menguasai tujuan belajaran dan dapat belajar mandiri (Nilasari dkk, 2016). Menurut Hamdani, (2011) dalam (Aditia, M. 
Taufik \& Muspiroh, 2013) tujuan penyusunan modul pembelajaran adalah menyediakan bahan ajar sesuai dengan tuntutan kurikulum dengan mempertimbangkan kebutuhan siswa. Keistimewaan dari modul pembelajaran ini adalah menggunakan pendekatan saintifik yang mengkolaborasikan dan kerjasama antara siswa dalam proses pembelajaran Abdul Majid dalam (Yansyah dkk, 2019). Pendekatan saintifik dalam pembelajaran mencakup proses: mengamati, menaya, mencoba, menalar dan mengkomunikasikan (Fadilaturrahmi, 2017).

\section{PENUTUP}

Berrikut adalah hasil dan pembahasan yang telah dijelaskan diatas, bahwasannya dapat disimpulkan bawa pengembangan modul pembelajaran berbasis saintifik dengan metode bermain peran pada mata pelajaran Basa Sunda menurut penilaian ketiga validator/ahli diperoleh penilaian sebagai berikut: penilaian dari ahli materi diperoleh hasil sangat valid atau sangat baik dengan persentase 90,3\%. Penilaian ahli Bahasa diperoleh hasil valid atau baik dengan persentase $71,1 \%$. Penilaian ahli desain diperoleh hasil sangat valid atau sangat baik dengan persentase 84,3\%. Dari hasil ketiga validator/ahli tersebut menunjukan modul pembelajaran yang dikembangkan valid atau baik diterapkan untuk membantu guru dalam memberikan materi pada siswa.

Penelitain ini memiliki kelemahan yaitu hanya sampai pada tahap validasi para ahli, peneliti menyarankan bagi yang akan menerapkan modul pembelajaran ini perlu dilakukan pengembangan lebih lanjut terhadap modul pembelajaran Basa Sunda berbasis saintifik dengan metode bermain peran sampai pada tahap uji coba modul pada siswa dan produksi modul.

\section{UCAPAN TERIMAKASIH}

Peneliti mengucapkan terimakasih kepada seluruh perangkat Universitas Ibn Khaldun Bogor yang telah memberikan bantuan dan dukungannhya dan kepada guru beserta murid MI Tarbiyatusshibya Bogor yang mana telah memberikan izin untuk melakukan penelitian.

\section{DAFTAR PUSTAKA}

Aditia, M. Taufik \& Muspiroh, N. (2013). Pengembangan Modul Pembelajaran Berbasis Sains, Lingkungan, Teknologi, Masyarakat Dan Islam (Salingtemasis) Dalam Meningkatkan Hasil Belajar Siswa Pada Konsep Ekosistem Kelas X Di SMA NU (Nadhatul Ulama) Lemahabang Kabupaten Cirebon. Scienticie Education, 2(2), 1-20.

Budi, A. S. (2019). Pengembangan Modul Metode Bermain Peran Tradisional Anak Untuk Pembelajaran Kelas 1 SD Tema 4 Subtema 1. Skripsi Universitas Sanata Dharma Yogyakarta.

Damayanti, Irma. (2017). Pengembangan Modul Berorientasi Pendekatan Saintifik Pada Mata Pelajaran IPA Materi Pokok Sistem Peredaran Darah Siswa Kelas XI MA Syech Yusuf. Skripsi Universitas Islam Negeri (UIN) Alauddin Makasar.

Daryanto. (2014). Pendekatan Pembelajaran Saintifik Kurikulum 2013. Yogyakarta: Gava Media.

Fadhilaturrahmi, F. (2017). Penerapan Pendekatan Saintifik Untuk Meningkatkan Kemampuan Komunikasi Matematika Peserta Didik di Sekolah Dasar. Eduhumaniora / Jurnal Pendidikan Dasar Kampus Cibiru. https://doi.org/10.17509/eh.v9i2.7078 
R. Dina Mulyasari- Salati Asmahasanah -Suyud Ari f. (2019). Attadib Journal Of Elementary Education, Vol. 3 (1), Juni 2019. 3(1).

Nilasari, E., Djatmika, E., \& Santoso, A. (2016). Pengaruh Penggunaan Modul Pembelajaran Kontekstual Terhadap Hasil Belajar Siswa Kelas V Sekolah Dasar. Jurnal Pendidikan-Teori, Penelitian, Dan Pengembangan, 1(7), 1399-1404. https://doi.org/10.17977/jp.v1i7.6583

Nurdiyansyah \& Musiqon. (2015). Pendekatan Pembelajaran Saintifik. Siduarjo: Nizamia Learning Center.

Nurdiyansyah \& Musiqon. (2015). Pendekatan Pembelajaran Saintifik. Siduarjo: Nizamia Learning Center.

Samsiah, Hidayah dan Salati. (2018). Pengaruh Pendekatan Kooperatif Tipe Role Playing Terhadap Keterampilan Berbicara Siswa Pada Mata Pelajaran Bahasa Indonesia. Attadib Journal Of Elementary Education, Vol. 2 (1).

Setiyadi, M. W. (2017). Pengembangan Modul Pembelajaran Biologi Berbasis Pendekatan Saintifik Untuk Meningkatkan Hasil Belajar Siswa. Journal of Educational Science and Technology (EST), 3(2), 102. https://doi.org/10.26858/est.v3i2.3468

Sugiyono. (2017). Statistika Untuk Penelitian. Bandung: ALFABETA

Susilo, Agus. (2015). Pengembangan Modul Berbasis Pembelajaran Saintifik Untuk Meningkatkan Kemampuan Aplikatif Dan Mencipta Siswa Dalam Proses Pembelajaran Akuntansi. Tesis Universitas Sebelas Maret Sukarta.

Wulandari, C. (2018). Estimasi Validasi Dan Respon Siswa Terhadap Bahan Ajar Multi Representasi: Definitif, Makroskopis, Mikroskopis, Simbolik Pada Materi Asam Basa. Phenomenon: Jurnal Pendidikan MIPA, 8(2), 52. https:// doi.org/10.21580/phen.2018.8.2.2498.

Yansyah, N. F., Asmahasanah, S., \& Hakiem, H. (2019). Pembelajaran Tematik Terpadu Melalui Pendekatan Saintifik Berbasis Lingkungan. Caruban: Jurnal Ilmiah Ilmu Pendidikan Dasar, 2(1), 40. https://doi.10.33603/v2i1.2349 